\title{
PARTISIPASI MASYARAKAT DALAM IMPLEMENTASI KEBIJAKAN PUBLIK TENTANG BPJS KESEHATAN DI KELURAHAN PURWOSARI KECAMATAN PURWOSARI KABUPATEN PASURUAN
}

\author{
Sahrani Rizal, Agus Tinus, Rohmad Widodo \\ FKIP Universitas Muhammadiyah Malang \\ Email : sahranirizal123@gmail.com
}

\begin{abstract}
ABSTRAK
Pemerintah dalam upaya pembangunan nasional terutama dalam aspek sumber daya manusia, pemerintah menerbitkan UU nomor 40 tahun 2004 tentang sistem jaminan sosial nasional (SJSN) dan UU nomor 24 tahun 2011 tentang badan penyelenggara jaminan sosial (UU BPJS). Sehingga pemerintah membentuk BPJS kesehatan, diharapkan agar seluruh warga negara Indonesia mendapat jaminan sosial kesehatan. Akan tetapi didalam masyarakat timbul persepsi-persepsi dalam program yang digalang oleh pemerintah ini, yang mana persepsi tersebut dapat mempengaruhi minat masyarakat untuk mendaftar menjadi peserta BPJS. Berdasarkan hal tersebut peneliti mengulas dengan melakukan penelitian mengenai "Partisipasi Masyarakat dalam Implementasi Kebijakan Publik tetang BPJS Kesehatan di Kelurahan Purwosari Kecamatan Purwosari Kabupaten Pasuruan”. Berdasarkan hal tersebut tujuan penelitian ini adalah untuk mengetahui seberapa besar partisipasi masyarakat dalam implementasi kebijakan mengenai BPJS kesehatan ini beserta apa hambatan dan solusinya.Adapun lokasi penelitian ini adalah di kantor cabang BPJS kesehatan kabupaten Pasuruan dan di kelurahan Purwosari kabupaten Pasuruan. Dengan sample penelitiannya adalah 3 (tiga) orang dari pihak BPJS kesehatan cabang Pasuruan dan 5 (lima) orang dari masyarakat kelurahan Purwosari. Alat pengumpul data yang di gunakan adalah berupa data primer dan data sekunder. Teknik analisa data yang digunakan adalah kualitatif. Hasil penelitiannya yaitu: (1) Partisipasi masyarakat dalam implementasi kebijakan publik mengenai BPJS Kesehatan di wilayah Kelurahan Purwosari sangat baik hingga mencapai angka 40\% dari keseluruhan penduduk Kelurahan Purwosari. Hal tersebut sejalan dengan pendapat Tilaar (2009:287) partisipasi adalah sebagai wujud dari keinginan untuk mengembangkan demokrasi melalui proses desentralisasi dimana diupayakan antara lain perlunya perencanaan dari bawah (button-up) dengan mengikut sertakan masyarakat dalam proses perencanaan dan pembangunan masyarakatnya. (2) hambatan-hambatan yang di dapat yaitu kurangnya komunikasi antara pemerintah dan juga masyarakat. Serta kurangnya sosialisasi yang dilakukan oleh pihak BPJS kesehatan. (3) untuk memperbaiki komunikasi masyarakat dan juga pemerintah agar setiap kebijakan yang dikeluarkan pemerintah dapat diterima dalam masyarakat dan juga agar masyarakat mempunyai kesadaran bahwa program BPJS kesehatan ini memang benar-benar dilakukan untuk kesejahteraan masyarakat.
\end{abstract}

Kata Kunci : Partisipasi, Implementasi, Kebijakan Publik, BPJS Kesehatan

\begin{abstract}
Government in national development efforts, especially in the aspect of human resources, the government issued Law No. 40 of 2004 on national social security system (Navigation) and Law No. 24 of 2011 concerning the social security agency (BPJS) . So the government formed BPJS healthy , it is expected that all Indonesian citizens receive social security health . But in public perceptions arise in a program at the girder by this government, which can affect the perception of public interest to register as a participant BPJS . Based on that review by researchers to conduct research on "Public Participation
\end{abstract}


in the Implementation of Public Policies on BPJS of Healhty at Purwosari Village Pasuruan Regency". Based on the purpose of this study was to determine how much public participation in the implementation of policies on health and its BPJS obstacles and solusinya.Adapun location of this research is in the district health BPJS branch office and in the village Purwosari Pasuruan Pasuruan . With the research sample is three members of the health BPJS Pasuruan branches and five members of the village community Purwosari . Data collection tool that is in use is a form of primary data and secondary data . Data analysis technique used was qualitative. The results of the research are: (1) Public participation in the implementation of public policies on BPJS in the Village Purwosari very well until reaching $40 \%$ of the total population of the Village Purwosari. This is consistent with the opinion of Tilaar (2009:287) participation is a manifestation of the desire to develop democracy through the decentralization process which sought, among others, the need for planning from below (button-up) by including the public in the process of planning and community development. (2) obstacles in the can that is the lack of communication between the government and communities. And lack of socialization conducted by the health BPJS. (3) to improve public communication and also the government that any government policies can be accepted in the society and also so that people have no awareness that health BPJS program is indeed done for the welfare of the community.

Keywords: Participation, Implementation, Public policy, Health insurance

\section{PENDAHULUAN}

Pembangunan Nasional merupakan upaya untuk meningkatkan seluruh aspek kehidupan masyarakat, bangsa, dan negara yang sekaligus merupakan proses pengembangan keseluruhan sistem penyelenggaraan negara untuk mewujudkan tujuan nasional yang sudah tercantum dalam pembukaan UUD 1945 alinea IV. Dalam hal ini berarti dalam pelaksanaan pembangunan nasional adalah untuk manusia dan bukan sebaliknya manusia untuk pembangunan. Dewasa ini dan jangka panjang, unsur manusia, unsur sosial budaya, dan unsur lainnya harus mendapat perhatian yang seimbang. Serta pembangunan nasional harus merata untuk seluruh masyarakat dan seluruh wilayah tanah air. Subjek dan objek pembangunan merupakan manusia dan masyarakat Indonesia, sehingga pembangunan harus berkepribadian Indonesia dan menghasilkan manusia dan masyarakat maju yang tetap berkepribadian Indonesia juga. Pembangunan dilaksanakan bersama oleh masyarakat dan pemerintah, masyarakat merupakan pelaku utama pembangunan dan pemerintah berkewajiban untuk mengarahkan, membimbing, serta menciptakan suasana yang menunjang. Kegiatan masyarakat dan kegiatan pemerintah saling mendukung, saling mengisi, dan saling melengkapi dalam satu kesatuan langkah menuju tercapainya tujuan pembangunan nasional.

Berdasarkan landasan filosofis diatas justru menyiratkan bahwa kedudukan jaminan sosial bagi seluruh rakyat Indonesia adalah bersifat urgen dan harus diperoleh setiap warga negara Indonesia. Pemerintah telah mencanangkan visi Indonesia 2025 menjadi negara maju pada tahun 2025. Pemerintah juga sepenuhnya menyadari bahwa kualitas sumber daya manusia (SDM) masih menjadi suatu tantangan dalam mewujudkan visi dimaksud. Menurut Janis (2012) menyatakan bahwa "para pakar dibidang SDM menyatakan bahwa kualitas SDM secara dominan ditentukan oleh kemudahan akses pada pendidikan dan fasilitas kesehatan yang berkualitas. Bahkan UNDP (United Nations Development Programme) memperkenalkan

Sahrani Rizal, dkk. Partisipasi Masyarakat dalam Implementasi Kebijakan Publik Tentang BPJSKesehatan di Kelurahan Purwosari Kecamatan Purwosari Kabupaten Pasuruan 
Indeks Pembangunan Manusia yang dua dari tiga indikatornya (peluang hidup, pengetahuan dan hidup layak) terkait dengan kesehatan”. Mempertimbangkan tingkat urgensi dari kesehatan, maka pemerintah baik di tingkat pusat maupun daerah telah melakukan beberapa upaya untuk meningkatkan kemudahan akses pada fasilitas kesehatan, di antaranya adalah dengan menerbitkan Undang-Undang Nomor 40 Tahun 2004 tentang Sistem Jaminan Sosial Nasional (UU SJSN) dan Undang-Undang Nomor 24 Tahun 2011 tentang Badan Penyelenggara Jaminan Sosial (UU BPJS).

Terbitnya kedua undang-undang dimaksud, pemerintah diwajibkan untuk memberikan lima jaminan dasar bagi seluruh masyarakat Indonesia yaitu jaminan kesehatan, kecelakaan kerja, kematian, pensiun, dan tunjangan hari tua. Jaminan yang dimaksud akan dibiayai oleh perseorangan, pemberi kerja, dan pemerintah. Pemerintah akan mulai menerapkan kebijakan Universal Health Coverage dalam hal pemberian pelayanan kesehatan kepada masyarakat, dimana sebelumnya Pemerintah (Pusat) hanya memberikan pelayanan kesehatan bagi Pegawai Negeri Sipil dan ABRI-Polisi. Kebijakan ini umumnya diterapkan di negara-negara yang menganut paham welfare state yaitu negara di Eropa Barat dan negara jajahan mereka serta beberapa negara Amerika Latin.

Perubahan kebijakan dalam layanan kesehatan dimaksud tidak terlepas dari himbauan World Health Assembly (WHA), pada sidang ke-58 pada tahun 2005 di Jenewa, agar setiap negara anggota memberikan akses terhadap pelayanan kesehatan kepada seluruh masyarakat khususnya bagi yang kurang mampu. Ada pun mekanisme yang digunakan adalah mekanisme asuransi kesehatan sosial. Seperti yang telah dilakukan pemerintah sejak Januari 2014 yang mana BPJS Kesehatan mulai beroperasi, sedangkan untuk BPJS Ketenagakerjaan sejak Januari 2015, dengan adanya badan-badan penyelenggara kesehatan tersebut diharapkan seluruh masyarakat mendapat jaminan kesehatan secara langsung, seperti yang diperintahkan oleh World Health Assembly (WHA). Hal ini pun sudah sejalan dengan UndangUndang Nomor 36 Tahun 2009 tentang Kesehatan yang menyatakan bahwa setiap warga negara mempunyai hak yang sama dalam memperoleh pelayanan kesehatan yang aman, bermutu, dan terjangkau.

Dalam mendukung jalannya kebijakan tentang kesehatan tersebut, di dalam implementasinya pemerintah membentuk dua Badan Penyelenggara Jaminan Sosial (BPJS) yaitu BPJS Kesehatan dan BPJS Ketenagakerjaan. BPJS Kesehatan akan menyelenggarakan program jaminan kesehatan dan BPJS Ketenagakerjaan akan menyelenggarakan program jaminan atas kecelakaan kerja, kematian, pensiun dan hari tua. Oleh sebab itu, UU SJSN menyatakan bahwa 4 (empat) BUMN di bidang asuransi yaitu PT Jamsostek (Persero), PT Taspen (Persero), PT Asabri (Persero), dan PT Askes (Persero) akan ditransformasi menjadi BPJS. Berkaitan dengan institusi BPJS Kesehatan, UU BPJS secara jelas menyatakan bahwa PT Askes (Persero) akan bertransformasi menjadi BPJS Kesehatan.

Dengan adanya Badan Penyelenggara Jaminan Sosial tersebut diharapkan warga negara Indonesia dapat menikmati jaminan sosial yang diberikan pemerintah. Agar seluruh masyarakat Indonesia baik dari semua kalangan masyarakat dapat menikmati fasilitas yang disediakan negara. 
Akan tetapi pada kenyataanya timbul persepsi masyarakat mengenai program BPJS kesehatan ini, hal tersebut dapat mempengaruhi minat masyarakat untuk mendaftar menjadi peserta BPJS. Oleh karena itu, dari beberapa paparan tersebut peneliti tertarik untuk mengambil judul "Partisipasi Masyarakat Dalam Implementasi Kebijakan Publik Tentang Badan Penyelenggara Jaminan Sosial (BPJS) Kesehatan Di Desa Purwosari, Kecamatan Purwosari, Kabupaten Pasuruan.

Berdasarkan latar belakang masalah yang telah diuraikan di atas, maka permasalahan dalam penelitian ini dapat dirumuskan sebagai berikut: a) Bagaimana partisipasi masyarakat dalam implementasi kebijakan publik tentang Badan Penyelenggaraan Jaminan Sosial (BPJS) kesehatan? b) Apa hambatan-hambatan yang dihadapi dalam implementasi kebijakan publik tentang Badan Penyelenggaraan Jaminan Sosial (BPJS) kesehatan? c) Bagaimana solusi agar masyarakat lebih tertarik dengan semua kebijakan pemerintah terutama kebijakan tentang Badan Penyelenggaraan Jaminan Sosial (BPJS) kesehatan?

\section{METODE}

Arikunto (dalam Gunawan, 2014:116) mengemukakan bahwa metode studi kasus sebagai salah satu jenis pendekatan deskriptif, penelitian yang dilakukan secara intensif, terperinci,dan mendalam terhadap suatu organisme (individu), lembaga atau gejala tertentu dengan daerah atau subjek yang sempit. Pada intinya menurut Salim (dalam Gunawan, 2014:116) studi kasus berusaha untuk menyoroti suatu keputusan itu diambil, bagaimana diterapkan dan apakah hasilnya.

Pendekatan kualitatif berasumsi bahwa manusia adalah makhluk yang aktif, yang mempunyai kebebasan kemauan, yang perilakunya hanya dapat dipahami dalam konteks budayanya, dan yang perilakunya tidak didasarkan pada hukum sebab akibat. Oleh sebab itu logis kalau penelitian yang menggunakan pendekatan kualitatif bertujuan untuk memahami objeknya, tidak untuk menemukan hukum-hukum, tidak untuk membuat generalisasi, melainkan membuat ekstrapolasi (Brannen dalam Alsa 2003:29).

Gunawan (2013:80) menyebutkan "penelitian kualitatif merupakan sebuah metode penelitian yang digunakan dalam mengungkapkan permasalahan dalam kehidupan kerja organisasi pemerintah, swasta, kemasyarakatan, kepemudaan, perempuan, olahraga, seni dan budaya, sehingga dapat dijadikan suatu kebijakan untuk dilaksanakan demi kesejahteraan bersama”.

Sugiyono (2014:9) Metode penelitian kualitatif adalah metode penelitian yang berlandaskan pada filsafat postpositivisme, digunakan untuk meneliti pada kondisi obyek yang alamiah, (sebagai lawannya adalah eksperimen) dimana peneliti adalah sebagai instrument kunci, teknik pengumpulan data dilakukan secara triangulasi (gabungan), analisis data bersifat induktif/kualitatif, dan hasil penelitian kualitatif lebih menekankan makna dari pada generalisasi.

Pendekatan yang digunakan dalam penelitian ini adalah pendekatan deskriptif dengan cara studi kasus (case study). Alasan peneliti melakukan penelitian dengan metode deskriptif dengan cara Studi Kasus (case study) adalah karena sesuai dengan sifat dan tujuan penelitian yang ingin diperoleh bukan menguji hipotesis tetapi berusaha mendapat gambaran nyata tentang "Partisipasi Masyarakat Terhadap

Sahrani Rizal, dkk. Partisipasi Masyarakat dalam Implementasi Kebijakan Publik Tentang BPJSKesehatan di Kelurahan Purwosari Kecamatan Purwosari Kabupaten Pasuruan 
Implementasi Kebijakan Publik Tentang BPJS Kesehatan di Kelurahan Purwosari, Kecamatan Purwosari, Kabupaten Pasuruan”.

Jenis penelitin yang digunakan adalah penelitian kualitatif karena akan menghasilkan data yang dikumpulkan berupa tulisan, kata-kata, gambar, dan bukan angka-angka. Jadi, selama proses penelitian ini, peneliti akan lebih lebih banyak berhubungan atau mengadakan kontak dengan subyek penelitian di kantor BPJS kesehatan lingkup Pandaan dan warga Kelurahan Purwosari.

Penelitian dilakukan di wilayah Rw. 01 - Rw. 08 Kel. Purwosari Kec. Purwosari Kab. Pasuruan dan Kantor Cabang BPJS kesehatan Pasuruan, tepatnya di Jl. Sultan Agung II No.1 Kota Pasuruan. 67118 Telp : (0343) 42745 Hotline: 08155907177.

Lokasi ini dipilih dikarenakan peneliti ingin mengetahui bagaimana partisipasi masyarakat Kel. Purwosari, Kec. Purwosari, Kab. Pasuruan ini didalam ikut serta dalam mewujudkan Indonesia yang sejahtera dengan dikeluarkannya kebijakan publik tentang BPJS kesehatan, dengan adanya lokasi kedua diharapkan peneliti mendapatkan hasil beserta rincian bagaimana minat dan partisipasi warga Kel. Purwosari.

Waktu penelitia dilakukan 3 minggu mulai dari tahap observasi, wawancara, dan dokumentasi. Peneliti melakukan kegiatan penelitian sesuai tahap-tahap yang telah ditentukan.

\section{HASIL DAN PEMBAHASAN}

Berdasarkan hasil penelitian yang telah diuraikan diatas akan dijelaskan lebih lanjut pada pembahasan dalam beberapa subbab, yaitu sebagai berikut: 1) Partisipasi masyarakat dalam implementasi kebijakan publik tentang Badan Penyelenggaraan Jaminan Sosial (BPJS) kesehatan, 2) Hambatan-hambatan yang dihadapi dalam implementasi kebijakan publik tentang Badan Penyelenggaraan Jaminan Sosial (BPJS) kesehatan, 3) Solusi agar masyarakat lebih tertarik dengan semua kebijakan pemerintah terutama kebijakan tentang Badan Penyelenggaraan Jaminan Sosial (BPJS) kesehatan. Adapun pembahsannya yaitu sebagai berikut:

Partisipasi masyarakat dalam implementasi kebijakan publik tentang Badan Penyelenggaraan Jaminan Sosial (BPJS) kesehatan

Berdasarkan hasil analisis penelitian dapat dikatakan bahwa Jaminan Kesehatan Nasional (JKN) merupakan bagian dari Sistem Jaminan Sosial Nasional (SJSN) yang diselenggarakan dengan menggunakan mekanisme asuransi kesehatan sosial yang bersifat wajib bagi seluruh rakyat Indonesia, maupun untuk warga negara asing yang bekerja paling singkat 6 (enam) bulan di Indonesia yang pengaturannya berdasarkan Undang-Undang Nomor 40 tahun 2004 tentang SJSN.

Keberhasilan suatu proses kebijakan publik tentang Jaminan Kesehatan Nasioanl (JKN) melalui program BPJS Kesehatan tidak lepas dari adanya partisipasi anggota masyarakatnya, baik sebagai suatu kesatuan sistem maupun sebagai individu yang merupakan bagian yang sangat integral, yang sangat penting dalam proses implementasi suatu kebijakan publik yang dikeluarkan oleh pemerintah, karena secara prinsip suatu kebijakan yang dikeluarkan pemerintah ditujukan untuk mewujudkan masyarakat yang sejahtera. Oleh karena itu berhasil atau tidaknya suatu kebijakan yang dikeluarkan pemerintah tidak hanya ditanggung oleh pemerintah atau lembaga yang mengeluarkan kebijakan tersebut, akan 
tetapi campur tangan masyarakat juga diperlukan agar suatu kebijakan bisa berjalan sesuai dengan yang diinginkan untuk mencipatakan kesejahteraan masyarakat.

Sedangkan menurut Tilaar (2009:287) partisipasi adalah sebagai wujud dari keinginan untuk mengembangkan demokrasi melalui proses desentralisasi dimana diupayakan antara lain perlunya perencanaan dari bawah (button-up) dengan mengikut sertakan masyarakat dalam proses perencanaan dan pembangunan masyarakatnya.

Dilihat dari teori diatas masyarakat dalam pengimplementasian keikutsertaanya masyarakat telah mengikuti serangkaian proses awal yang diwajibkan seperti persyaratan pendaftaran kepesertaan hingga iuran wajib setiap bulan. Adapun persyaratan menjadi peserta BPJS kesehatan yang wajib dipenuhi yaitu sebagai berikut: 1) Foto copy kartu KTP, 2) Foto copy kartu keluarga, 3) Foto berwarna $3 \times 4,4)$ Foto copy buku tabungan. Menjadi peserta BPJS kesehatan wajib membayar iuran sesuai dengan golongan kelas rawat yang dipilih saat mendaftar. Sesuai dengan Perpres nomor 19 tahun 2016 iuran PBPU/BP/ peserta mandiri, yaitu sebagai berikut: 1) Kelas 1 sebesar Rp. 80.000,- per jiwa per bulan, 2) Kelas 2 sebesar Rp. 51.000,- per jiwa per bulan, 3) Kelas 3 sebesar Rp. 25.500,- per jiwa per bulan. Dengan adanya iuran wajib tersebut diharapkan masyarakat betanggung jawab akan keikutsertaanya menjadi peserta BPJS kesehatan. Untuk masyarakat pekerja penerima upah berdasarkan pasal 15 ayat (1) dan (2) undang-undang Nomor 24 Tahun 2011 tentang Badan Penyelenggaraan Jaminan Sosial, maka: "Pekerja penerima upah wajib didaftarkan menjadi peserta BPJS kesehatan oleh perusahaan atau pabrik dimana tempatnya ia bekerja”.
Berdasarkan data yang sudah didapatkan dan didukung dengan teori yang sudah diuraikan di atas dapat disimpulkan bahwa partisipasi masyarakat dalam implementasi kebijakan publik mengenai BPJS Kesehatan di wilayah Kelurahan Purwosari sangat baik dikarenakan presentasenya mencapai $40 \%$ warga yang mengikuti BPJS Kesehatan, dan untuk sisanya warga mengikuti BPJS Ketenagakerjaan dan juga KIS (Kartu Indonesia Sehat).

Dalam pengimplementasian keikutsertaanya masyarakat telah mengikuti serangkaian proses awal yang diwajibkan seperti persyaratan pendaftaran kepesertaan hingga iuran wajib setiap bulan. Masayarakat peserta BPJS kesehatan diharapkan bertanggungjawab atas keikutsertaannya karena keberhasilan suatu kebijkan yang dikeluarkan pemerintah tidak luput dari partisipasi dari warganya.

\section{Hambatan-hambatan yang dihadapi dalam implementasi kebijakan publik tentang Badan Penyelenggaraan Jaminan Sosial (BPJS) kesehatan.}

Berdasarkan hasil analisis data diatas terdapat hambatan-hambatan yang dialami masyarakat maupun dari pihak BPJS kesehatan, hal tersebut lumrah dikarenakan dalam mengeluarkan suatu kebijkan publik pasti ada beberapa pihak yang mendukung dan tidak mendukung. Hambatan-hambatan yang dialami pihak BPJS Kesehatan yaitu kurangnya kesadaran masyarakat banyak masyarakat yang mendaftar pada saat mereka sakit dan juga banyaknya masyarakat yang tidak mengetahui bagaimana prosedure rujukan beserta prosedure pelayanan di dalam faskesfaskes primer.

Hambatan-hambatan yang dialami masyarakat yaitu dalam pelayanan yang diberikan oleh mitra kerja BPJS Kesehatan

Sahrani Rizal, dkk. Partisipasi Masyarakat dalam Implementasi Kebijakan Publik Tentang BPJSKesehatan di Kelurahan Purwosari Kecamatan Purwosari Kabupaten Pasuruan 
seperti puskesmas, apotek, rumah sakit dan sebagainya. Banyaknya persyaratan yang diajukan dalam proses perujukan ketempat pengobatan yang lebih baik dan untuk kualitas obat banyak perbedaan dari kelas umum diluar BPJS Kesehatan hingga masyarakat peserta BPJS Kesehatan mulai dari kelas 3 hingga 1 terdapat perbedaan obat yang sangat mencolok antara pasien umum dan pasien BPJS Kesehatan. Dan juga masih banyaknya obat yang belum menjadi mitra dari BPJS Kesehatan sehingga masyarakat membayar sendiri obat yang belum terdaftar di dalam BPJS Kesehatan. Bagi pihak BPJS Kesehatan hambatan yang merka alami selama ini yaitu kurangnya kesadaran masyarakat banyak masyarakat yang mendaftar pada saat mereka sakit dan juga banyaknya masyarakat yang tidak mengetahui bagaimana prosedur rujukan.

Berdasarkan data yang sudah di dapat diatas dapat disimpulkan bahwa hambatanhambatan di atas adalah kurangnya komunikasi antara pemerintah dan juga masyarakat. Serta kurangnya sosialisasi yang dilakukan oleh pihak BPJS kesehatan.

\section{Solusi agar masyarakat lebih tertarik dengan semua kebijakan pemerintah terutama kebijakan tentang Badan Penyelenggaraan Jaminan Sosial (BPJS) kesehatan}

Berdasarkan hasil analisis data yang telah diuraikan di atas mengungkapkan bahwa pihak BPJS kesehatan dan masyarakat mengungkapkan solusi mengenai hambatan-hambatan tersebut, agar untuk kedepannya pihak BPJS kesehatan maupun masyarakat lebih terjalin kerjasama untuk mewujudkan tujuan nasional dengan dipelopori program BPJS kesehatan ini.
Solusi yang diutarakan oleh pihak BPJS Kesehatan yaitu peserta BPJS Kesehatan diberi pelayanan-pelayanan baru agar lebih tertarik untuk ikut dalam program pemerintah ini. Baik dari segi pelayanan diwaktu mendaftar BPJS Kesehatan maupun pada waktu peserta jatuh sakit, untuk pembayaran juga dipermudah, agar tidak terjadi keterlambatan pembayaran bagi peserta BPJS Kesehatan, dan juga dalam hal sosialisai kepada masyarakat pihak BPJS Kesehatan mulai memperpadat jadwal sosialisai agar masyarakat tidak lagi bingung dalam mendaftar maupun pada waktu memakai kartu BPJS Kesehatan tersebut. Hal ini dilakukan agar untuk kedepannya partisipasi masyarakat bertambah dikarenakan memang sifat dari Jaminan Sosial ini wajib dan juga agar masyarakat tidak bingung mengenai program BPJS kesehatan ini.

Masyarakat juga mempunyai solusi mengenai kebijakan publik, yaitu sebagai berikut: jangan sampai ada perbedaan antara pasien umum dan pasien BPJS Kesehatan. Kemudian untuk pelayanan mengenai obat diharapkan untuk kedepanya lebih diperbaiki lagi dan lebih diperbanyak dalam membangun mitra kerja dengan perusahaan obat yang baik. Dan juga mengenai iuran diharapkan jangan sampai naik karena peserta BPJS Kesehatan mandiri rata-rata masyarakat menengah kebawah. Untuk sosialisasi diharapkan pihak BPJS Kesehatan turun langsung kelapangan, untuk memberikan sosialisasi mengenai bagaimana prosedur pendaftaran kartu BPJS Kesehatan, prosedur rujukan dan prosedur lain-lain.

Jadi dari uraian di atas dapat disimpulkan bahwa dalam menyikapi hambatan-hambatan yang dilakukan oleh 
masyarakat dan juga pihak BPJS kesehatan adalah untuk memperbaiki komunikasi masyarakat dan juga pemerintah agar setiap kebijakan yang dikeluarkan pemerintah dapat diterima dalam masyarakat dan juga agar masyarakat mempunyai kesadaran bahwa program BPJS kesehatan ini memang benar-benar dilakukan untuk kesejahteraan masyarakat.

\section{SIMPULAN}

Berdasarkan hasil penelitian dapat disimpulkan bahwa: 1. Partisipasi masyarakat dalam implementasi kebijakan publik mengenai BPJS Kesehatan di wilayah Kelurahan Purwosari sangat baik dikarenakan presentasenya mencapai 40\% warga yang mengikuti BPJS Kesehatan, dan untuk sisanya warga mengikuti BPJS Ketenagakerjaan dan juga KIS (Kartu Indonesia Sehat). Dalam pengimplementasian keikutsertaanya masyarakat telah mengikuti serangkaian proses awal yang diwajibkan seperti persyaratan pendaftaran kepesertaan hingga iuran wajib setiap bulan. 2. Hambatanhambatan yang dialami masyarakat (peserta BPJS Kesehatan) yaitu dalam pelayanan yang diberikan oleh mitra kerja BPJS Kesehatan seperti puskesmas, apotek, rumah sakit dan sebagainya. Banyaknya persyaratan yang diajukan dalam proses perujukan ketempat pengobatan yang lebih baik dan untuk kualitas obat banyak perbedaan dari kelas umum diluar BPJS Kesehatan hingga masyarakat peserta BPJS Kesehatan mulai dari kelas 3 hingga 1 terdapat perbedaan obat yang sangat mencolok antara pasien umum dan pasien BPJS Kesehatan. dan juga masih banyaknya obat yang belum menjadi mitra dari BPJS Kesehatan sehingga masyarakat membayar sendiri obat yang belum terdaftar didalam BPJS Kesehatan.
Sedangkan hambatan-hambatan yang dialami pihak BPJS Kesehatan hambatan yang merka alami selama ini yaitu kurangnya kesadaran masyarakat banyak masyarakat yang mendaftar pada saat mereka sakit dan juga banyaknya masyarakat yang tidak mengetahui bagaimana prosedure rujukan. 3. Solusi yang diutarakan oleh pihak BPJS Kesehatan yaitu peserta BPJS Kesehatan diberi pelayanan-pelayanan baru agar lebih tertarik untuk ikut dalam program pemerintah ini. Baik dari segi pelayanan diwaktu mendaftar BPJS Kesehatan maupun pada waktu peserta jatuh sakit, untuk pembayaran juga dipermudah, agar tidak terjadi keterlambatan pembayaran bagi peserta BPJS Kesehatan, dan juga dalam hal sosialisai kepada masyarakat pihak BPJS Kesehatan mulai memperpadat sosialisai agar masyarakat tidak lagi bingung dalam mendaftar maupun pada waktu memakai kartu BPJS Kesehatan tersebut. Bukan hanya pihak BPJS akan tetapi masyarakat (peserta BPJS Kesehatan) mengutarakan solusi yaitu jangan sampai ada perbedaan antara pasien umum dan pasien BPJS Kesehatan. Kemudian untuk pelayanan mengenai obat diharapkan untuk kedepanya lebih diperbaiki lagi dan lebih diperbanyak dalam membangun mitra kerja dengan perusahaan obat yang baik. Dan juga mengenai iuran diharapkan jangan sampai naik karena peserta BPJS Kesehatan mandiri rata-rata masyarakat menengah kebawah. Untuk sosialisasi diharapkan pihak BPJS Kesehatan turun langsung kelapangan, untuk memberikan sosialisasi mengenai bagaimana prosedure pendaftaran kartu BPJS Kesehatan, prosedure rujukan dan prosedure lain-lain. Agar masyarakat mempunyai kesadaran bahwa program BPJS Kesehatan ini memang benar-benar dilakukan untuk kesejahteraan masyarakat.

Sahrani Rizal, dkk. Partisipasi Masyarakat dalam Implementasi Kebijakan Publik Tentang BPJSKesehatan di Kelurahan Purwosari Kecamatan Purwosari Kabupaten Pasuruan 


\section{DAFTAR PUSTAKA}

Alsa, Asmadi. 2003. Pendekatan Kuantitatif Kualitatif Serta Kombinasinya Dalam Penelitian Psikologi. Yogyakarta: Pustaka Belajar.

BPJS Kesehatan. 2014. Jaminan Kesehatan (Meliputi Peserta dan Pelayanan Kesehatan). (Online). (http://bpjs-kesehatan.go.id), diakses 27 Januari 2016.

Dependiknas. 1999. Kamus Besar Bahasa Indonesia. Jakarta: Balai Pustaka.

Gunawan, Imam. 2014. Metode Penelitian Kualitatif Teori Dan Praktik. Jakarta: PT Bumi Aksara.

Sugiyono. 2014. Metode Penelitian Kuantitatif, Kualitatif, Dan R \& D. Bandung: CV. Alfabeta.

Tilaar, H. A. R. Dab Riant Nugroho. 2009. Kebijakan Pendidikan. Yogyakarta: Bina Aksara.

BPJS: Undang-Undang Nomor 40 Tahun 2004 tentang Sistem Jaminan Sosial Nasional (UU SJSN). (Online), (http://www.bpjs-kesehatan. go.id), diakses 16 Desember 2015.

BPJS: Undang-Undang Nomor 24 Tahun 2011 tentang Badan Penyelenggara Jaminan Sosial (UU BPJS). (Online), (http://www. bpjs-kesehatan.go.id), diakses 16 Desember 2015. 